\title{
Damage Control Orthopedics in Mangled Limb and Open Fractures
}

\author{
*Ricardo Monreal \\ Centro Médico MEDEX, República de Panamá 3065 2do piso, South America
}

Submission: October 26, 2017; Published: November 01, 2017

*Corresponding author: Ricardo Monreal, Centro Médico MEDEX, República de Panamá 3065 2do piso, San Isidro-Lima, Perú, South America, Email: rmonreal59@yahoo.es

\section{Abstract}

Damage control orthopaedics has proven to be a powerful tool for the orthopedic surgeon who treats an unstable trauma victim or a patient in extremis and for the borderline patient as well. A limited form of damage control orthopaedics (limb damage control orthopaedics) is a rational alternative for the treatment of isolated, complex limb injuries.

Abbreviation: DCO: Damage Control Orthopedics; LEAP: Lower Extremity Assessment Project; CTA: Computerized Tomographic Angiography; VAC: Vacuum-assisted wound closure

\section{Introduction}

The term damage control was adopted from the US Navy policy on controlling damage aboard a ship while being able to continue on with its mission [1]. In surgery the term refers to a systematic approach to caring for the most severely injured patients. In developing countries traffic accidents which have reached the proportions of global epidemic, and Damage Control Orthopedics (DCO) is a gradual approach for the management of patients with multiple injuries. It is ideal for patients presenting an unstable physiological state providing temporary stabilization of fractures reducing, at the same the biological effects of surgery [2].

The benefits of his approach have been demonstrated in numerous studies within the past two decades [3-5].

Damage control orthopaedics is an extension of the principles of damage control surgery as applied to musculoskeletal trauma approach based on the principle of limiting and minimizing the invasiveness of the operative procedure so that the procedure induced inflammatory response second hit is not detrimental to the patient. Limb damage control with external fixation corrects local metabolic disturbances, corrects local hypothermia, and reverses coagulopathy. The most important type of extremity injury that benefits from a limb damage control approach is the mangled leg. The use of external fixation in the treatment of mangled limb has become the mainstay of damage control orthopaedics.
The mangled limb is defined as a limb with injury to three of four extremity systems [6] with the systems defined as the soft tissues, nerves, blood supply, and bone [7]. The initial treatment decision is between immediate limb salvage and amputation. The traditional belief that amputation led to superior outcomes following severe lower extremity injury is not supported by the Lower Extremity Assessment Project (LEAP) study [8]. The treatment of open fractures, especially in patients with multiple injuries, the main priority is to save the patient's life and it is essential a rapid and rigid fixation of the open fracture, as well as the treatment of other life-threatening injuries [9]. Type I and II open fractures of the extremities reacted well to treatment, while type III wounds constituted a major problem with the incidence of infection in as many as $24 \%$ of cases $[10,11]$. Other than performing radical surgical treatments, the best way to prevent infection is to eliminate dead spaces where liquidhematoma accumulates, as they are excellent grounds for the growth of bacteria [12].

\section{General Principles}

i. Determining the adequacy of limb perfusion and the neurological. Doppler or conventional angiography assessment can be helpful; as well the Computerized Tomographic Angiography (CTA). Specific c bony injuries that carry a higher risk of an associated vascular injury include complex fractures of the proximal tibial plateau, often the result of a fracture-dislocation of the knee. 


\section{Orthopedics and Rheumatology Open Access Journal}

ii. Clinical assessment must be repeated at regular intervals.

iii. Conditions that will require immediate surgery include: vascular impairment, compartment syndrome (Figure 1), some multiply injured patients with open fractures (Figure 2) or if the wound is heavily contaminated by marine, agricultural, or sewage matter (Figure 3).

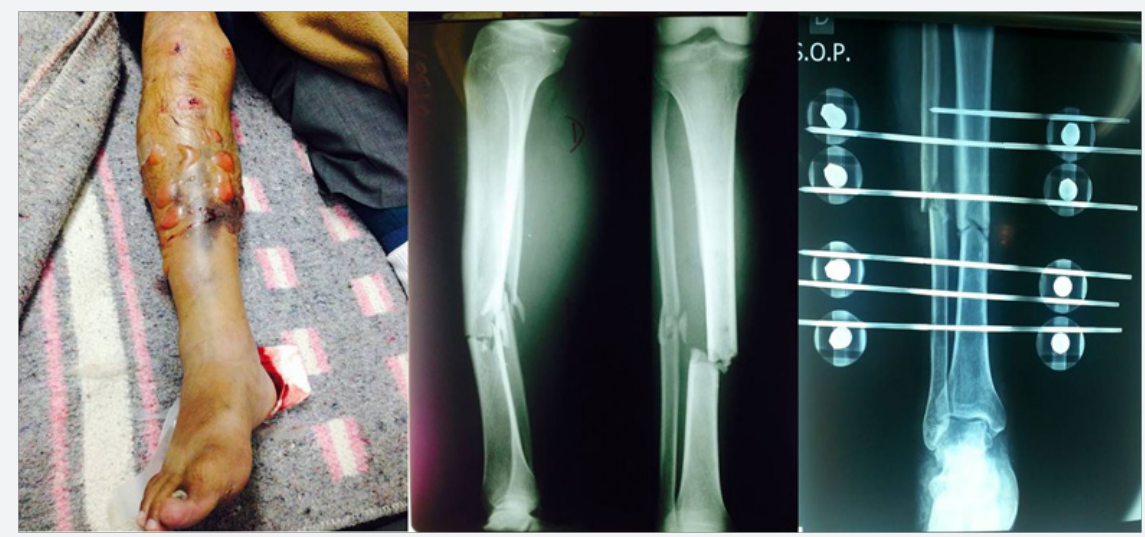

Figure 1: Closed tibia fracture associated with compartmental syndrome treated with external fixator.

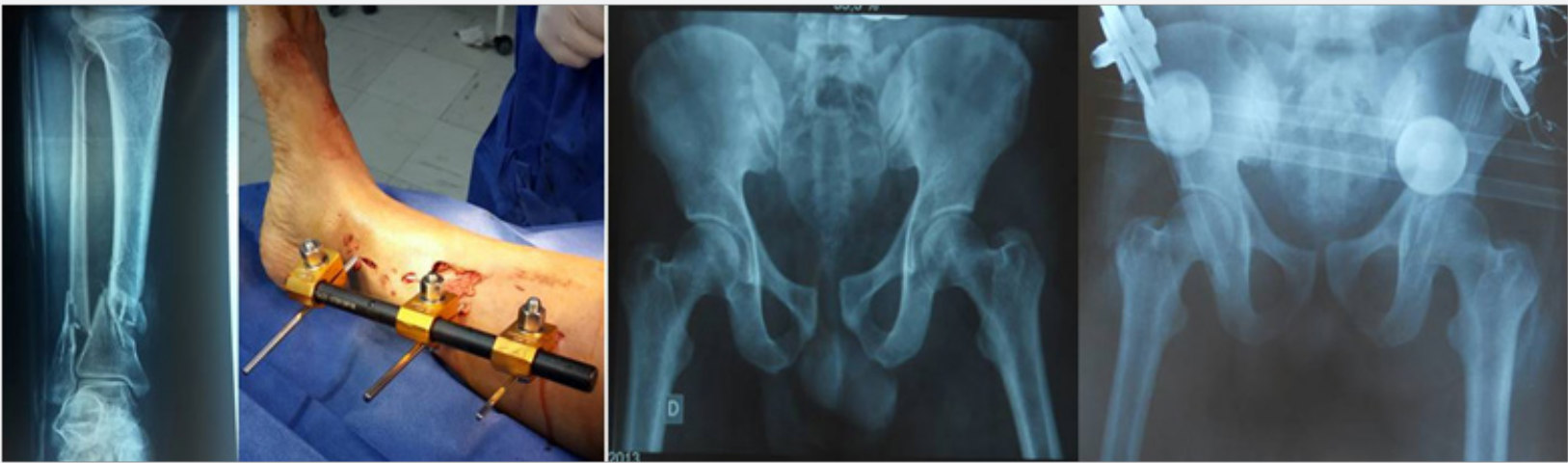

Figure 2: Initial external fixation was performed at the same time of the pelvis and open tibia fracture.

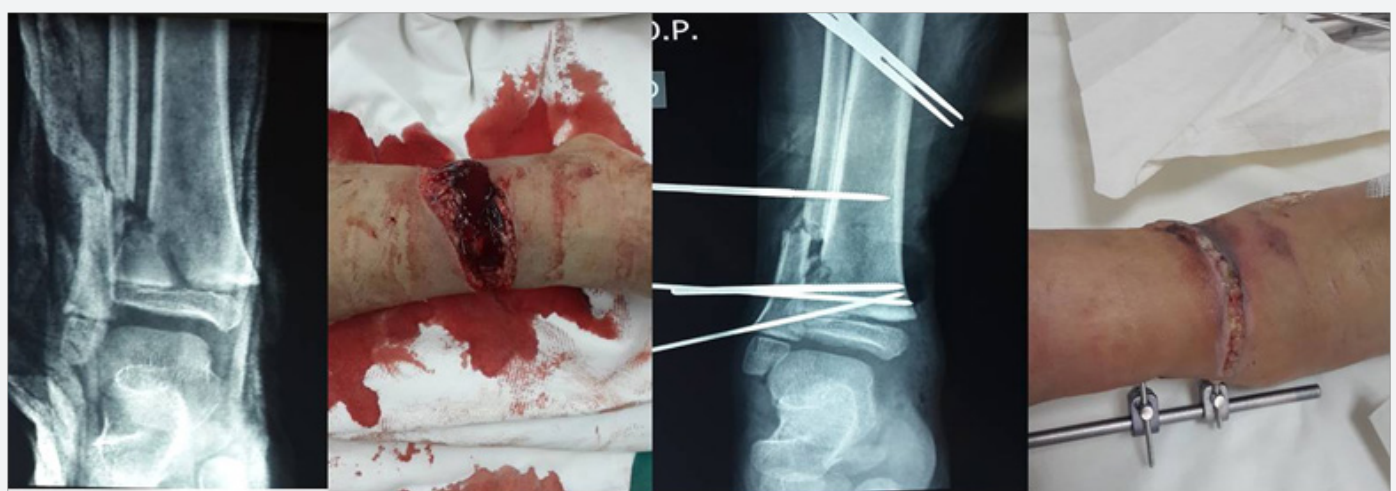

Figure 3: Contaminated open distal tibia fracture in an 8 years old patient treated with external fixation.

iv. In the emergency room, the wound and soft tissues should only be handled to remove gross contamination; a picture should be taken for documentation purposes.

v. A saline-soaked dressing should be applied and covered with an impermeable fi $\mathrm{lm}$ to prevent desiccation before the application of a splint. vi. Intravenous antibiotics should be started as early as possible and should continue until the first wound debridement.

\section{External Fixator Montages}

Include segmental leg injury, multilevel fractures of the proximal and distal segments of the leg, or an ischemic leg with 
vascular compromise.

\section{Adjunctive Measures}

a. Antibiotic Bead Pouches: Antibiotic bead pouches are useful for grossly contaminated open fracture wounds that will need additional staged debridement's, and after debridement cannot be closed primarily.

b. Negative Pressure Wound Therapy: Vacuum-assisted wound closure (VAC) is an application of negative pressure wound therapy which has increasingly been used for treating open fracture wounds. The VAC appears to increase the rate of granulation tissue formation compared with saline dressing-treated wounds and may also reduce bacterial counts in wounds.

c. Antibiotic Nails: The antibiotic nail can be thought of as an intermediate step in a staged treatment of combined bony and soft tissue injuries of the lower extremity where definitive internal fixation is not safe because the soft tissue envelope is not intact.

\section{Conclusion}

The Damage Control Orthopedics (DCO) with external fixation is the most valuable aid when an efficient solution to war and civil injuries to the extremities and pelvis is required.

i. The most important type of extremity injury that benefits from a limb damage control approach is the mangled leg.

ii. The use of external fixation in the treatment of mangled limb has become the mainstay of damage control orthopaedics.

iii. Adjunctive measures such as antibiotic beads, VAC, and antibiotic nails are useful. iv. The method of choice for primary stabilization of bone fragments in mangled limb and open fractures is External Fixator.

\section{References}

1. Surface Ship Survivability (2004) Naval Warfare Publication, Washington, DC, USA.

2. Giannoudis PV, Giannoudi M, Stavlas P (2009) Orthopaedics damage control: lessons learned. Injury 40S4: S47-S52.

3. Sala F, Capitani D, Castelli F, La Maida GA, Lovisetti G, et al. (2010) Alternative fixation method for open femoral fractures from a damage control orthopaedics perspective. Injury 41(2): 161-168.

4. Mitković M, Bumbasirević M, Grubor P, Milenković S, Micić I, et al. (2013) Nature and results of treatment of war wounds caused by cluster bombs. Acta Chir Iugosl 60(2): 41-47.

5. Grubor P, Grubor M, Tanjga R, Mitković MM (2013) Dilemmas in the treatment of tibial diaphyseal fractures. Acta Chir Iugosl 60(2): 33-39.

6. Wolinsky PR, Webb LX, Harvey EJ, Tejwani NC (2011) The mangled limb: salvage versus amputation. Instr Course Lect 60: 27-34.

7. Hansen Jr ST (1989) Overview of the severely traumatized lower limb: reconstruction versus amputation. Clin Orthop Relat Res 243: 17-19.

8. Cannada LK, Jones AL (2006) Demographic, social and economic variables that affect lower extremity injury outcomes. Injury Int J Care Injured 37(12): 1109-1116.

9. Van den Bossche MRI', Broos PL, Rommens PM (1995) Open fractures of the femoral shaft, treated with osteosynthesis or temporary external fixation. Injury 26(5): 323-325.

10. Charles M Court-Brown, Margaret M McQueen, Awf A Quaba (1997) Management of Open Fractures. The Bone \& Joint Journal, pp. 505.

11. Grubor P (1996) The role of external fixation in the treatment of war wounds, Glas srpski, Banja Luka, South Europe.

12. Kraljević Lj (1976) The importance of morphological characteristics of gunshot wounds inflicted by missiles with high initial velocity of the primary surgical treatment. Acta Chirlugosl, Novi Sad, pp. 120-124.

\section{Your next submission with Juniper Publishers} will reach you the below assets

- Quality Editorial service

- Swift Peer Review

- Reprints availability

- E-prints Service

- Manuscript Podcast for convenient understanding

- Global attainment for your research

- Manuscript accessibility in different formats

( Pdf, E-pub, Full Text, Audio)

- Unceasing customer service

Track the below URL for one-step submission https://juniperpublishers.com/online-submission.php 